\title{
The Effect of Independence, Leadership Style, and Organizational Commitments to Internal Auditor Performance in Inspectorate of Bali Province
}

\author{
I Gst. B Ngr. P. Putra ${ }^{1}$ Ni Nengah Seri Ekayani ${ }^{2}$ Ni Kadek Supraba Wati ${ }^{3}$ \\ \{ngurahpanji.putra@gmail.com ${ }^{1}$, seriekayani1965@gmail.com² ${ }^{2}$, suprabawati.kadek@gmail.com ${ }^{3}$ \}
}

Warmadewa University, Denpasar, Bali, Indonesia ${ }^{1,2,3}$

\begin{abstract}
The purpose of this study was to examine the effect of independence, leadership style, and organizational commitment on the performance of internal auditors in the Inspectorate of the Province of Bali. The method of determining the sample in this study is the purposive sampling method. The population of this research is all senior auditors working at the Bali Provincial Inspectorate Office. The sample in this study amounted to 30 respondents. The questionnaire became the data collection method used in this study. Multiple linear regression analysis researchers used to examine the effect of the independent and dependent variables. The test results show that independence, leadership style, and organizational commitment have a positive effect on the auditor's internal performance. This can be interpreted that the independence, leadership style, and organizational commitment the higher the internal auditor's performance is also getting better.
\end{abstract}

Keywords: Independence, Leadership Style, Organizational Commitment, Internal Auditor Performance.

\section{Introduction}

Internal audit can be interpreted as a process carried out by company employees to determine the level of accuracy of financial information and the company's operational processes compared to established operational standards. The effectiveness of the role of internal audit can be assessed through its ability to prevent and detect and correct if there are acts of accounting fraud in an organization (Hery, 2017: 96).

Auditing is considered very important for the company, because if the audit results of an auditor on a company's financial statements are declared reasonable, then the stakeholders both internal and external will be easily to make the decisions. Auditor performance is the ability of an auditor to produce findings from audit activities carried out (Adelia and Budiartha, 2016). Performance can be measured through applicable standards, where quality is related to the quality generated from a task, while quantity is the amount that can be produced within a predetermined period of time, while timeliness is the completion of tasks in accordance with the planned time (Listiya, 2016 ). The good performance of an auditor is needed to support the level of success in carrying out audit tasks.

Issues or cases that occur in the domestic scandal can be seen from the case that happened to the middle auditor PT. Jasa Marga, Sigit Yuhoharto who is indicated to have received bribes from Setia Budi (Inactive General Manager of PT. Jasa Marga, Purbaleunyi Branch). BPK's senior auditor, Sigit Yugoharto, is suspected of getting a gift or promise to do or not do something, or because he has done or not finished something which is then associated with his position as auditor. This is certainly not appropriate and contradictory when related to its obligation to conduct an examination of PT Jasa Marga (Persero) in 2017 (www.news.detik.com).

The phenomenon in Indonesia, especially in Bali, is the corruption case in the Tukad Mati Project. The latest news is that the Financial and Development Supervisory Agency (BPKP) has collected audit results from the total state losses. Audit results from the BPKP found that the value of losses showed a nominal value of Rp. 834,835,043.00. Investigators from the Denpasar Prosecutor's Office have named three suspects in connection with the Tukad Mati development corruption case, including Wayan Seraman and AA. Gede Dalem as an official at the Badung PUPR Service, and I Wayan Sutaya as the President Director of PT. Undagi Jaya Mandiri. A report from a local resident related to the Tukad Mati system was the beginning of an investigation by the Denpasar Kejari (www.baliberkarya.com). 
The reason we were doing this research because there are inconsistent result which mean the result of the previous research was not conclusive yet. It can be shown with the table below:

Table 1. The Result of Previous Research

\begin{tabular}{ccccc}
\hline Researchers & $\begin{array}{c}\text { Internal Auditor } \\
\text { Performance }\end{array}$ & Independence & Leadership Style & $\begin{array}{c}\text { Organizational } \\
\text { Commitment }\end{array}$ \\
\hline Widhi (2014) & $\sqrt{ }$ & $(-)$ & & \\
Kompiang dan & $\sqrt{ }$ & $(+)$ & $(\mathrm{x})$ & \\
Dharma (2013) & $\sqrt{ }$ & & $(+)$ \\
Widhi (2014) & $\sqrt{ }$ & & $(\mathrm{x})$ \\
Setiyadi dan & & & \\
Rasmini (2016) & $\sqrt{ }$ & & $(+)$ \\
Widhi (2014), & & & \\
Prameswari dan & $\sqrt{ }$ & & \\
Nazar (2015), & & & \\
Setiyadi dan & & & \\
Rasmini (2016) & & & \\
\hline
\end{tabular}

\section{Literature Review}

\subsection{Agency Theory}

Agency theory explains the conflict of interest that occurs between the principal as the business owner and the agent as the company's management. The principal has an interest in advancing his business ventures, while the management has an interest in his personal welfare. This information asymmetry that occurs between the two parties is the reason for the important role of the auditor profession (Wulandari, 2017).

\subsection{Theory of Attitude and Behaviour}

Theory of Attitude and Behavior states that a person's behavior is determined for what people want to do (attitude), what they think they will do (social rules), what they can do (habits) and with the consequences of the behavior they think (Harlynda, 2011).

\subsection{Independence}

Independence describes the attitude of not being influenced and impartial to anyone (neutral). Fakhri (2016) states that it is very difficult not to take sides, willing or unwilling to have partiality, in this case the alignment meant is something that is true.

\subsection{Leadership Style}

Leadership style is defined as a way for a leader to be able to invite and influence the mindset and actions of colleagues or subordinates to be able and willing to take action in order to achieve the goals set (Samsuddin, 2018).

\subsection{Organizational Commitment}

Organizational commitment describes an action and attitude of individuals to always be loyal and bound to the goals of the organization. Each manager is recommended to be able to increase the level of job satisfaction of his employees so as to be able to create a better commitment to the organization. This will improve employee work productivity and facilitate the process of achieving business goals (Samsuddin, 2018).

\section{Research Methods}

This research is located at the Bali Provincial Inspectorate Office. The independent variable in this research is independence, leadership style, and organizational commitment while the dependent variable 
is the internal auditor's performance. This study used a questionnaire of 30 items using primary data types. The sample is part of the entire population that is considered to have the same characteristics by researchers (Sugiyono, 2016: 81). The researchers used purposive sampling as a method of determining the sample. The multiple linear regression analysis was used to test the effect between the independent variable and the dependent variable.

\section{Result \& Discussion}

The results of multiple linear regression testing are presented in Table 2 .

\begin{tabular}{|c|c|c|c|c|c|c|}
\hline \multirow[b]{2}{*}{ Model } & & \multicolumn{2}{|c|}{$\begin{array}{l}\text { Unstandarized } \\
\text { Coefficients }\end{array}$} & \multicolumn{2}{|l|}{$\begin{array}{c}\text { Standardized } \\
\text { Coefficients }\end{array}$} & \multirow[b]{2}{*}{ Sig. } \\
\hline & & $\mathrm{B}$ & Std. Error & Beta & $\mathrm{t}$ & \\
\hline \multirow[t]{4}{*}{1} & (Constant) & $-31,475$ & 13,971 & & $-2,253$ & 0,033 \\
\hline & Independence & 0,516 & 0,079 & 0,557 & 6,558 & 0,000 \\
\hline & Leadership style & 0,705 & 0,133 & 0,451 & 5,303 & 0,000 \\
\hline & $\begin{array}{l}\text { Organizational } \\
\text { Commitment }\end{array}$ & 0,232 & 0,059 & 0,322 & 3,925 & 0,001 \\
\hline $\mathrm{R}$ & $=0,910$ & & & & & \\
\hline Adjusted R & Square $=0,808$ & & & & & \\
\hline$F_{\text {hitung }}$ & $=41,676$ & & & & & \\
\hline Sig. $F_{\text {hitung }}$ & $=0,000$ & & & & & \\
\hline
\end{tabular}

\section{1 Model Test}

This model test consists of the determination test $\left(\mathrm{R}^{2}\right)$ and the $\mathrm{F}$ test. Based on the table above it can be seen that the value of adjusted $r$ square $\left(R^{2}\right)=0.808$ or which means that the variables Independence (X1), Leadership Style (X2), and Organizational Commitment (X3) affect the Internal Auditor's Performance by $80.8 \%$ and Other variables outside of this study affect the rest of $19.2 \%$.

Based on the results of the statistical test above shows that the value of the $F$ test of significance is equal to $0,000<5$ percent. These results represent the Independence, Leadership Style, and Organizational Commitment simultaneously affecting the Internal Auditor's Performance at the Inspectorate of the Bali Province.

\subsection{Hypothesis testing}

\subsubsection{The Effect of Independence on Internal Auditor Performance at The Inspectorate of The Province of Bali}

The conclusion drawing criteria is if the significance value $>0.05$ then it can be concluded that the independent variable does not significantly influence the dependent variable, and vice versa (Ghozali, 2016: 99). The regression coefficient for the independence variable is 0.516 with a significance of 0.000 (below 0.05). This means that the independence variable has a significant positive effect on internal auditor performance (H1 accepted). Furthermore, if related to this research, it can be explained that the higher the level of independence of an auditor, the better the performance of the auditor, in this case the internal auditor at the Bali Provincial Inspectorate. Independence can be interpreted as an attitude of not being influenced and impartial to anyone (neutral). With an independent attitude, an auditor will not be able to be influenced by other parties, and is based on audit evidence and actual conditions that occur in the field (objective). The results of this study are consistent with research conducted by Kompiang and Dharma (2013).

\subsubsection{The Influence of Leadership Style on Internal Auditor Performance on Inspectroat Province of Bali}

The value of the regression coefficient for the leadership style variable is 0.705 with a significance of 0,000 (below 0.05). This means that the leadership style variable has a significant positive effect on internal auditor performance ( $\mathrm{H} 2$ accepted). If related to this research, it can be explained that the better 
leadership style of an auditor, the better the performance of the auditor, in this case the internal auditor at the Inspectorate of the Province of Bali. A good leader is one who has the ability to increase work motivation and influence the mindset and actions of his subordinates to achieve organizational goals. The results of this study support the research conducted by Setiyadi and Rasmini (2016).

\subsubsection{Effect of Organizational Commitment on Internal Auditor Performance at The Inspectorate of The Province of Bali}

The regression coefficient value for the variable organizational commitment is 0.232 with a significance of 0.001 (below 0.05). This means that the organizational commitment variable has a significant positive effect on internal auditor performance ( $\mathrm{H} 3$ accepted). When associated with this research it can be explained that the higher the commitment of an auditor, the better the performance of the auditor, in this case the internal auditor at the Inspectorate of the Province of Bali. Organizational commitment emphasizes the level of employee loyalty and attachment to an organization. Increasing one's organizational commitment, the loyalty is also increasing for the organization. An employee with a high level of organizational commitment will always try to get involved and fight for the interests of the organization. The results of this study support the research conducted by Setiyadi and Rasmini (2016).

\section{Conclusions and Suggestions}

\subsection{Conclusions}

The conclusions that can be drawn from this study are adjusted with the results obtained are independence, leadership style, and organizational commitment have a positive effect on internal auditor performance at the Inspectorate of the Province of Bali

\subsection{Limitations of Research and Suggestions}

The limitation of this study is that it is only carried out at the Inspectorate of the Province of Bali more specifically, namely the internal auditor's process. In this study, researchers only used three variables. For the next researcher, can add variables that are able to influence the performance of auditors such as professionalism and education level. The results of this study can be considered for application by the Inspectorate of the Province of Bali. The application process can be in the form of an appeal to all auditors to maintain their independence in making audit decisions based on applicable auditing standards, applying a democratic leadership style without losing firmness so that the auditor can be more comfortable giving his opinion regarding auditing and the problems that occur in the institution, and maintaining commitment organization through better collaboration in the audit team.

\section{References}

[1]Adelia, Lukyta Arumsari., dan Budiartha I Ketut. (2016). Pengaruh Profesionalisme Auditor, Independensi Auditor, Etika Profesi, Budaya Organisasi, Dan Gaya Kepemimpinan Terhadap Kinerja Auditor Pada Kantor Akuntan Publik Di Bali.

[2]Prameswari, Dwi Anjani., dan Nazar, Muhammad Rafki. 2015. Pengaruh Penerapan Integritas, Obyektivitas, Kerahasiaan, Kompetensi Dan Komitmen Organisasi Terhadap Kinerja Internal Auditor.

[3]Fakhri Amir, Muhammad. 2016. Makna Independensi dalam Audit. diakses pada tanggal 30 Maret 2019 01:32:15, http://www.kompasnia.com/ bugiszone/5748767d8623bd690a343c0d/maknaindependensi-dalam-audit.

[4]Ghozali, I., 2018. Aplikasi Analisis Multivariate dengan Program IBM SPSS 25 Edisi 9. Semarang: Badan Penerbit Universitas Diponogoro.

[5]Harlynda Anindya Putri. 2011. Pengaruh Aturan Etika Dan Independensi Terhadap Kepuasan Kerja Internal Auditor, Dengan Profesionalisme Sebagai Variabel Intervening (Studi Empiris Pada Internal Auditor Bpkp Semarang).

[6]Hery. 2017. Potret Profesi Auditing Internal, Penerbit Alfabeta, Bandung.

[7]Kompiang Martina Dinata Putri \& Dharma Suputra, I.D.G. 2013. Pengaruh Independensi, Profesionalisme, Dan Etika Profesi Terhadap Kinerja Auditor Pada Kantor Akuntan Publik Di Bali.

[8]Listiya, Nuraini. 2016. Pengaruh Independensi, Gaya Kepemimpinan Dan Budaya Organisasi Terhadap Kinerja Auditor (Studi Empiris Pada Kantor Akuntan Publik Yogyakarta dan Solo). 
[9]Samsuddin, Harun. 2018. Kinerja Karyawan: Tinjauan dari Dimensi Gaya, Kepemimpinan, Budaya Organisasi dan Komitmen Organisasi. Penerbit Indomedia Pustaka.

[10]Widhi, Saputro Nugroho. 2014. Pengaruh Independensi, Gaya Kepemimpinan, Komitmen Organisasi Dan Pemahaman Good Governance Terhadap Kinerja Auditor Pemerintah.

[11]Setiyadi, I Nyoman \& Rasmini, I Ketut. 2016. Pengaruh Gaya Kepemimpinan, Komitmen Organisasi, Dan Sistem Informasi Akuntansi Pada Kinerja Auditor Kantor Akuntan Publik.

[12]Wulandari, Ni Kadek Sri. 2017. Pengaruh Pemahaman Good Governance, Komitmen Organisasi, Kerahasiaan, Integritas Dan Obyektivitas Terhadap Kinerja Auditor Internal Pemerintah Daerah Pada BPKP RI Perwakilan Provinsi Bali.

[13]Sugiyono. 2016. Metode Penelitian Kuantitatif, Kualitatif, dan R\&D. Penerbit Alfabeta, Bandung. 